\title{
Peran Persepsi tentang Lingkungan Kerja Psikososial terhadap Komitmen Organisasional pada Lembaga Pendidikan Islam
}

\author{
Ugung Dwi Ario Wibowo \\ Program Doktor Fakultas Psikologi Universitas Padjajaran Bandung \\ Email: ugungs@yahoo.com
}

\begin{abstract}
This objective of this research is to analyzed the role of perception toward psychosocial work environment on organizational commitment, a quantitative study to teacher and employee of Islamic education institution. This studyusesthe population ofthe subject are 47 teachers and employee. Datawere collectedthrough2scalesarePerception toward Psychosocial Work EnvironmentScale, andOrganizational CommitmentScale. Analysis method in this research used simple regression analysis. The data were analyzed by simple regression analysis. The result is $F_{\text {score }}>F_{\text {table }}(35,184>4,050)$, with $t_{\text {score }}(5,932)>t_{\text {table }}(2,021)$, and the totaleffect $=43,9 \%$. That result show that Hypothesis null $\left(H_{o}\right)$ rejected, it is mean perception toward psychosocial work environment contribute significantly to theorganizational commitment.The implication of this research is islamic psychosocial work environment is important to increasing the organizational commitment in islamic education institution.
\end{abstract}

Key words: perception toward psychosocial work environment, organizational commitment.

Penelitian ini bertujuan untuk menganalisis sejauh mana persepsi tentang lingkungan kerja psikososial berperan terhadap komitmen organisasional pada pada para guru dan karyawan lembaga pendidikan islam. Penelitian ini menggunakan populasi subjek sejumlah 47 guru dan karyawan LPA Putra Harapan di Purwokerto. Data digali melalui 2 skala yaitu Skala Persepsi tentang Lingkungan Kerja Psikososial, dan Skala Komitmen Organisasional.Metode analisis penelitian ini menggunakan analisis regresi sederhana. Hasil perhitungan menunjukkan $F_{\text {hitung }}>F_{\text {tabel }}(35,184>4,050)$, dengan hasil $t$ hitung sebesar 5,932 $>t_{\text {tabel }}$ (2,021), dengan total pengaruh sumbangan efektif sebesar 43,9\%. Hasil tersebut menunjukkan Hipothesis null $\left(H_{o}\right)$ ditolak, artinya bahwa persepsi tentang ligkungan kerja psikososial berpengaruh secara nyata (signifikan) terhadap komitmen organisasional. Implikasi penelitian ini yaitu pentingnya lingkungan kerja psikosial yang islami untuk meningkatkan komitmen organisasi pada lembaga pendidikan islam.

Kata kunci: persepsi tentang ligkungan kerja psikososial, komitmen organisasional

\section{Pendahuluan}

Lembaga pendidikan merupakan salah satu jenis lembaga jasa yang penting dalam dinamika perindustrian. Berbagai kebijakan disusun untuk mengikuti perkembangan bisnis lembaga pendidikan, termasuk dinamika kerja yang pada organisasi industri di seluruh dunia telah bergeser dari bekerja secara individual menjadi bekerja secara teamwork (kerja tim) dan network (berjejaring), apalagi lembaga pendidikan swasta.

Lembaga pendidikan swasta di kota Purwokerto terdapat puluhan, salah satunya yaitu Lembaga Pengembangan Anak (LPA) Putra Harapan Purwokerto. LPA ini merupakan lembaga pendidikan usia dini (playgroup dan taman kanak-kanak/TK), pendidikan dasar (sekolah dasar/SD), dan pendidikan menengah (sekolah menengah pertama/SMP dan sekolah menengah atas/SMA) di bawah Yayasan Islam Al Mu'thie yang berdiri sejak tahun 1996, notabene sebagaimana lembaga pendidikan yang terus berkembang. 
LPA Putra Harapan bukan hanya mengembangkan pendidikan formal, namun juga pendidikan informal dengan dikembangkannya sistem full day care, pendidikan anak usia dini, serta kelas inklusi sejak tahun 2003. Kelas inklusi LPA Putra Harapan pada tahun 2008 ini memiliki 6 peserta didik autis hingga saat ini telah mendidik lebih dari 100 anak berkebutuhan khusus. Begitu pula di jenjang pendidikan menengah, SMP dan SMA Putra Harapan memilih sebagai sekolah inklusi yang menampung anak berkebutuhan khusus. Dengan jumlah total sumber daya manusia (SDM) yang bekerja di atas 1 tahun sejumlah 62 guru dan karyawan, LPA Putra Harapan menjadi salah satu lembaga pendidikan swasta dengan jumlah SDM yang besar di Purwokerto.

\section{Tabel 1.}

\section{Data Guru \& Karyawan LPA Putra Harapan Purwokerto Tahun 2013}

\begin{tabular}{|l|l|l|}
\hline No & Institusi LPA Putra Harapan & Jumlah \\
\hline 1 & Playgroup dan TKIT Putra Harapan & 24 \\
\hline 2 & SDIT Putra Harapan & 25 \\
\hline 3 & SMPIT Putra Harapan & 13 \\
\hline
\end{tabular}

Sumber: Dokumentasi LPA Putra Harapan, Desember 2014

Dengan semakin banyak SDM yang dimiliki, maka salah satu yang dijaga dalam hal stabilisasi dinamika organisasi yaitu komitmen organisasional. Komitmen organisasi merupakan salah satu kunci dalam ketercapaian produktivitas dan pemeliharaan organisasi terutama ketika ditinjau dalam perspektif psikologi organisasi dan eksistensi organisasi dalam jangka panjang.

Komitmen organisasi menurut Robbins dan Judge (2007) didefinisikan sebagai suatu keadaan dimana seorang individu memihak organisasi serta tujuan-tujuan dan keinginannya untuk mempertahankan keangotaannya dalam organisasi. Meyer dan Allen (1991) menyatakan bahwa komitmen organisasional sebagai kondisi psikologis yang menjadi karakteristik hubungan antara karyawan dengan organisasinya dan memiliki implikasi terhadap keputusannya untuk terus menjadi anggota organisasi.

Meyer dan Allen menemukan dan memperkenalkan teori memiliki konstrukmulti dimensional yang terdiri dan membedakan antara tiga-komponen (afektif, kelanjutan, dan normatif) dalam kerangka konseptual komitmen organisasi dianggap sebagai keadaan psikologis. Pembagian dimensi komitmen organisasional menjadi tiga komponen, terdiri atas: (1) continuance commitment (komitmen kesinambungan), merupakan suatu komitmen yang didasarkan atas kebutuhan rasional atau prinsip untung rugi; (2) normative commitment (komitmen normatif), merupakan komitmen yang didasarkan pada norma yang ada di dalam diri karyawan; dan (3) affective commitment (komitmen afektif), merupakan suatu komitmen karena ingin terikat dengan organisasi, dengan kata lain berkaitan perasaan berkewajiban karyawan untuk stand by karena adanya persamaan nilai pribadi dan nilai organisasi.

Bagi perusahaan, komitmen organisasional meningkatkan masa kerja karyawan, membatasi intensi turn-over, serta memperbesar kepuasaan kerja. Menurut Steers (dalam Sopiah, 2008) komitmen karyawan pada organisasi tidak terjadi begitu saja, tetapi melalui proses yang panjang dan bertahap. Salah satu yang berpengaruh dalam menciptakan komitmen yaitu kharakteristik organisasi yang salah satunya diwakili persepsi yang positif terhadap lingkungan kerja.

Jewel dan Siegell (1998) membagi lingkungan kerja menjadi dua yaitu lingkungan fisik dan lingkungan psikososial. Persepsi karyawan tentang ingkungan kerja fisik yang positif, seperti: keadaan hawa, suhu, cahaya, serta alat-alat yang sepadan dengan ukuran dan konstruksi 
tubuh anggota badan manusia, akan membuat karyawan aman, nyaman, dan merasa dihargai. Persepsi lingkungan kerja psikososial. Handoko (2011) menyatakan lingkungan kerja psikososial adalah kondisi yang berkenan dengan kepercayaan, nilai, sikap, pandangan antara kebudayaan yang berkembang dalam suatu perusahaan atau organisasi.

Beberapa penelitian tentang variabel-variabel kharakteristik organisasi seperti iklim organisasi, budaya organisasi, hubungan rekan sejawat, dan hubungan atasanbawahan/supervisory, yang kemudian disebut persepsi karyawan pada lingkungan psikososial kerja terhadap komitmen organisasional (Octaviyani, 2010). Maka, persepsi tentang lingkungan kerja psikososial menjadi penting untuk dilihat seberapa besar perannya terhadap kemunculan komitmen organisasional, terutama pada suatu lembaga pendidikan islam.

Berangkat dari pemaparan diatas, perlu untuk dilakukan penelitian tentang peran persepsi lingkungan kerja psikososial terhadap komitmen organisasional. Perumusan masalah dalam penelitian ini adalah: bagaimana peran persepsi tentang lingkungan kerja psikososial terhadap komitmen organisasional?

Tujuan yang hendak dicapai dalam penelitian ini adalah untuk mencari gambaran sejauh mana pengaruh persepsi lingkungan kerja psikososial terhadap komitmen organisasional.

\section{Metode Penelitian}

Penelitian ini tergolong penelitian kuantitatif berdasarkan jenis data dan prosedur menganalisis datanya.Variabel independen dalam penelitian ini yaitu: persepsi lingkungan kerja psikososial. Variabel dependen di penelitian ini yaitu: komitmen organisasional.

Partisipan dalam penelitian direncanakan adalah guru dan karyawan di Lembaga Pengembangan Anak (LPA) Putra Harapan, yang terdiri guru PAUD, guru TKIT, guru SDIT, guru SMPIT, guru SMAIT, dan karyawan di lembaga pendidikan tersebut.

Prosedur pengumpulan data dalam penelitian ini menggunakan dua skala, yaitu Skala Persepsi tentang Lingkungan Kerja Psikososial dan Skala Komitmen Organisasional. Jumlah skala yang kembali dan layak dianalisis sejumlah 47 skala.Sistem penilaian pada tiga skala tersebut di atas dengan metode skala intensitas Likert yang diminta memilih satu di antara 5 alternatif jawaban.

Uji hipotesis dengan analisis regresi sederhana. Penelitian ini difokuskan pada bagaimana pengaruh persepsi lingkungan kerja psikososial terhadap komitmen organisasional. Dengan demikian akan dilihat peran dan hubungan antara kedua variabel.

\section{Hasil}

Berdasarkan hasil perhitungan analisis alur struktur tersebut, maka berikut ini merupakan temuan data hasil perhitungan dalam analisis regresi sederhana dengan menggunakan program SPSS For WindowsRelease 17.00, yaitu:

1. R atau koefisien korelasi

Dari hasil analisis didapat nilai koefisien korelasi (R) sebesar 0,662, berarti bahwa ada hubungan antara persepsi tentang lingkungan kerja psikososial dengan komitmen organisasional sebesar $66,2 \%$.

2. R square atau koefisien determinasi

Tabel 2.

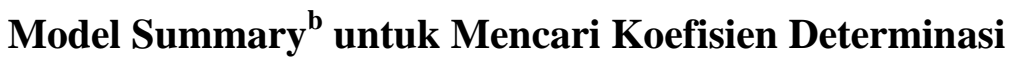




\begin{tabular}{|c|c|c|c|c|c|c|c|c|c|}
\hline \multirow[b]{2}{*}{ Model } & \multirow[b]{2}{*}{$\mathrm{R}$} & \multirow[b]{2}{*}{$\begin{array}{l}\mathrm{R} \\
\text { Square }\end{array}$} & \multirow[b]{2}{*}{$\begin{array}{l}\text { Adjusted } \\
\mathrm{R} \text { Square }\end{array}$} & \multirow[b]{2}{*}{$\begin{array}{l}\text { Std. Error of } \\
\text { the Estimate }\end{array}$} & \multicolumn{5}{|c|}{ Change Statistics } \\
\hline & & & & & $\begin{array}{l}R \text { Square } \\
\text { Change }\end{array}$ & $\begin{array}{l}\mathrm{F} \\
\text { Change }\end{array}$ & df1 & df2 & $\begin{array}{l}\text { Sig. } \\
\text { Change }\end{array}$ \\
\hline 1 & $.662^{\mathrm{a}}$ & .439 & .426 & 12.443 & .439 & 35.184 & 1 & 45 & .000 \\
\hline
\end{tabular}

a. Predictors: (Constant), Persepsi Lingkungan

b. Dependent Variable: Komitmen Organisasi

Koefisien determinasi menerangkan seberapa variasi $\mathrm{Y}$ yang disebabkan oleh $\mathrm{X}$. Dari tabel (terlampir) dapat dibaca nilai $\mathrm{R}_{\text {square }}(\mathrm{R} 2)$ sebesar 0,439 artinya bahwa variasi yang terjadi terhadap komitmen organisasional sebesar $43,9 \%$ disebabkan oleh persepsi tentang lingkungan kerja psikososial dan sisanya sebesar $56,1 \%$ dipengaruhi oleh hal-hal lain di luar persamaan ini.

\section{Perhitungan ANOVA}

\section{Tabel 3.}

\section{ANOVA ${ }^{b}$}

\begin{tabular}{|l|l|l|l|l|l|}
\hline Model & Sum of Squares & Df & Mean Square & F & Sig. \\
\hline Regression & 5447.533 & 1 & 5447.533 & 35.184 & $.000^{\mathrm{a}}$ \\
Residual & 6967.276 & 45 & 154.828 & & \\
Total & 12414.809 & 46 & & & \\
\hline
\end{tabular}
a. Predictors: (Constant), Persepsi Lingkungan

b. Dependent Variable: Komitmen Organisasi

Didapat nilai $F_{\text {hitung }}$ pada tabel ANOVA di atas yaitu sebesar 35,184. Sementara itu $F$ table pada taraf signifikansi 5\% yaitu sebesar 4,05. Dari hasil di atas dapat dilihat bahwa $F_{\text {hitung }}>$ $\mathrm{F}_{\text {tabel }}(35,184>4,050)$, disimpulkan bahwa model liniear, $\mathrm{Y}=\mathrm{a}=\mathrm{bX}$ sudah tepat dan dapat digunakan. Dapat dilihat bahwa nilai probabilitas adalah $0,000<0,05$, berarti model diterima atau dapat disimpulkan bahwa bentuk persamaan linear $\mathrm{Y}=\mathrm{a}+\mathrm{bX}$ sudah tepat. Didapat persamaan regresi $\mathrm{Y}=-3,190+1,275 \mathrm{X}$

4. Uji Signifikansi

Tabel 4.

\section{Coefficients $^{\mathrm{a}}$}

\begin{tabular}{|c|c|c|c|c|c|}
\hline \multirow[b]{2}{*}{ Model } & \multicolumn{2}{|c|}{$\begin{array}{l}\text { Unstandardized } \\
\text { Coefficients }\end{array}$} & \multirow{2}{*}{\begin{tabular}{|l}
$\begin{array}{l}\text { Standardized } \\
\text { Coefficients }\end{array}$ \\
Beta
\end{tabular}} & \multirow[b]{2}{*}{$\mathrm{T}$} & \multirow[b]{2}{*}{ Sig. } \\
\hline & B & Std. Error & & & \\
\hline$($ Constant $)$ & -3.190 & 14.466 & & -.221 & .826 \\
\hline $\begin{array}{l}\text { Persepsi } \\
\text { Lingkungan }\end{array}$ & 1.275 & .215 & .662 & 5.932 & .000 \\
\hline
\end{tabular}

a. Predictors: (Constant), Persepsi Lingkungan

b. Dependent Variable: Komitmen Organisasi

Didapatkan hasil thitung sebesar 5,932.

Sementara itu $t_{\text {table }}$ dengan tingkat signifikansi 0,05 dan derajat bebas 23 di mana dilakukan di dua sisi (2 tailed) di dapatkan $t_{\text {table }}(1 / 20,05 ; 23)=2,021$. 
Karena $t_{\text {hitung }}>t_{\text {table }}(5,932>2,021)$, maka Ho ditolak, artinya bahwa persepsi tentang lingkungan kerja psikososial berpengaruh secara nyata (signifikan) terhadap komitmen organisasional.

\section{Pembahasan}

Berdasarkan hasil analisis penelitian, ketiga variabel penelitian diukur dengan menggunakan skala dan dilakukan uji regresi sederhana untuk melihat pengaruh dari variabel yang satu kepada variabel lainnya. Dari hasil analisis data didapatkan data bahwa ada pengaruh persepsi tentang lingkungan kerja psikososial berperan signifikan terhadap komitmen organisasional pada guru dan karyawan LPA Putra Harapan di Purwokerto, dibuktikan dengan F hitung $>\mathrm{F}$ tabel $(35,184>4,050)$ sehingga sesuai dengan kriteria uji simultan adalah tolak $\mathrm{H}_{0}$, artinya variabel persepsi tentang lingkungan kerja psikososial berpengaruh terhadap komitmen organisasional. Diperkuat dengan hasil $\mathrm{t}_{\text {hitung }}$ sebesar 5,932 yang $>\mathrm{t}$ table $(2,021)$ yang maka artinya Ho ditolak, artinya bahwa persepsi tentang lingkungan kerja psikososial berpengaruh secara nyata (signifikan) terhadap komitmen organisasional.

Hasil penelitian juga menunjukkan bahwa berdasarkan analisis regresi sederhana ditemukan adanya pengaruh yang signifikan antara persepsi tentang lingkungan kerja psikososial terhadap komitmen organisasional dengan total pengaruh sebesar $43,9 \%$, serta sisanya sebesar $56,1 \%$ merupakan pengaruh variabel lain yang tidak diteliti terhadap munculnya komitmen organisasional.

Kontribusi variabel persepsi tentang lingkungan kerja psikososial terhadap komitmen organisasional menyumbangkan kontribusi koefisien korelasi sebesar 66,2\% atau lebih dari $50 \%$, sehingga bisa dikatakan pemilihan variabel dalam penelitian ini sudah bagus karena sudah bisa menyerap informasi variabel yang berpengaruh terhadap komitmen organisasional. Lembaga pendidikan islam yang menganut prinsip-prinsip organisasi syariah membedakan diri dari organisasi non syariah, di mana organisasi syariah menekankan pada tata aturan yang mengatur tata kerja, proses kerja, kinerja, dan tujuan akhir bekerja yang bukan semata-mata mencari keuntungan melainkan juga sebagai ibadah. Keanggotaan pada suatu organisasi syariah akan diikuti dengan komitmen terhadap organisasinya sesuai dengan akad kerja dan aturan bekerja sebagai urusan ibadah dan muamalah.

Beberapa variabel yang termasuk dalam persepsi pengalaman selama bekerja adalah: perasaan dihargai, persepsi tentang gaji atau imbalan, keterlibatan sosial, dan keterandalan organisasi, yang kemudian disebut persepsi lingkungan psikososial kerja. Perasaan dihargai yang dimaksud di sini adalah sejauh mana individu yang merasa dipentingkan atau diperlukan dalam mengemban misi organisasi (Allen dan Meyer, 1997). Pada suatu lembaga pendidikan islam yang memandang bahwa keberadaan manajemen dan lingkungan psikososial akan mengikat anggotanya agar yang dilakukan selalu berada dalam koridor syariah. Hal ini berlaku bagi setiap Muslim, siapa pun, kapan pun dan di mana pun. Inilah sebenarnya penjabaran dari kaidah ushul yang menyatakan "al aslu fi al-af'al attaqoyyadu bi al-hukmusy syar'i", yakni hukum asal suatu perbuatan adalah terikat pada hukum syara yang lima, yakni wajib, sunah, mubah, makruh dan haram.

Dengan lingkungan psikososial kerja yang syariah, setiap muslim akan saling mengingatkan dan mampu membedakan secara jelas dan tegas perihal halal tidaknya, atau haram tidaknya suatu kegiatan manajerial yang akan dilakukannya. Aktivitas yang halal akan dilanjutkannya, sementara yang haram akan ditinggalkannya semata-mata untuk menggapai keridhaan Allah Swt.

Adapun konsep lingkungan psikososial dalam bingkai persaudaraan sesama muslim hingga memunculkan komitmen organisasi dijabarkan dalam tahapan sebagai berikut: (1) fase 
taaruf, yaitu sikap mengenali dan bersilaturahim antara sesama muslim pada suatu lingkungan/organisasi; (2) fase tafahum, yaitu sikap memahami dalam konteks ukhuwatul muslimin di suatu lingkungan/organisasi; (3) fase ta'awun, yaitu sikap menolong sesama muslim yang dalam kesusahan di dalam suatu lingkungan/organisasi; dan (4) fase tafakul, yaitu sikap rela berkorban untuk organisasi syariah atau saudaranya demi nama baik agamanya dan tegaknya syariah. Bentuk takaful merupakan bentuk komitmen yang tinggi dalam suatu organisasi atau jamaah (Ash Shati, 2003), di mana Rasulullah bersabda:

"Seorang mukmin adalah cermin bagi saudara mukmin yang lain. Seorang mukmin adalah saudara bagi mukmin yang lain, saling melengkapi dan menutupi kekurangan, serta melindunginya dari belakang” (Abu Dawud, kitab Adab, bab Nasihat)

Lingkungan kerja psikososial yang dipersepsi positif karena menjalankan etika kerja islami berpengaruh positif dan signifikan terhadap komitmen organisasi. Berdasarkan regresi sederhana hipotesis tersebut terkonfirmasi. Hasil ini sejalan dengan penelitian Rahman (2006) yang dilakukan sebelumnya di Malaysia. Karena para karyawan muslim mengetahui bahwa norma islami mereka berkorespondensi dengan nilai-nilai institusinya, maka komitmen organisasinya terutama komitmen afektif dan normatif akan meningkat. Komitmen afektif berkaitan dengan emosional, identifikasi dan keterlibatan dalam organisasi. Sedangkan komitmen normatif berhubungan dengan perasaan wajib berada dalam organisasi karena norma yang diyakini benar.Menurut Ash Shafti (2003), komitmen untuk berpegang erat dalam jamaah islamiyah difirmankan Allah, Swt dalam QS. Ali Imran, ayat 103 dan ayat 105:

"Dan berpeganglah kamu semua kepada tali (agama) Allah, dan janganlah kamu bercerai berai...."

"Dan janganlah kamu menyerupai orang-orang yang bercerai berai dan berselisih sesudah datang keterangan yang jelas kepada mereka. Mereka itulah orang-orang yang mendapat siksa yang berat".

Penelitian ini memperkuat teori sebelumnya bahwa komitmen karyawan pada organisasi dipengaruhi situasi psikososial di lingkungan kerjanya sebagai pengalaman seseorang dalam setting kerja, Robbins dan Judge (2007) dan Steers (dalam Oktorita, dkk, 2001) mengidentifikasi tiga ada faktor yang mempengaruhi komitmen karyawan pada organisasi, yaitu: (1) ciri pribadi pekerja, (2) ciri pekerjaan, dan (3) pengalaman kerja, seperti keterandalan organisasi di masa lampau dan cara pekerja-pekerja lain mengutarakan dan bagaimana karyawan mempersepsi lingkungan kerjanya sebagai suatu interaksi psiskososial. Implementasinya, seorang yang persepsi tentang lingkungan kerja psikososial yang yang islami akan meningkatkan komitmen organisasinya terhadap organisasi yang islami, dalam penelitian ini yakni lembaga pendidikan islam.

\section{Simpulan dan Saran}

Berdasarkan hasil uraian-uraian yang telah dilakukan pada bab sebelumnya, maka penulis mengambil kesimpulan sebagai berikut: persepsi tentang lingkungan kerja psikososial berpengaruh secara signifikan terhadap komitmen organisasional pada lembaga pendidikan islam, dalam hal ini yaitu guru dan karyawan LPA Putra Harapan di Purwokerto dengan total pengaruh sebesar $43,9 \%$.

Berdasarkan hasil penelitian peneliti memberi saran bagi para guru dan karyawan maupun bagi manajemen lembaga pendidikan islam Putra Harapan, perlu dipertimbangkan untuk meningkatkan lingkungan kerja psikososial terutama lingkungan psikososial islami yang sudah positif, karena terbukti bahwa dua hal tersebut mempengaruhi komitmen organisasional pada lembaga pendidikan islam. Bagi peneliti selanjutnya, bisa mengembangkan penelitian lebih luas, 
mengkaitkan dengan variabel lain dan populasi yang berbeda jenis organisasi, sehingga memberikan gambaran yang lebih komprehensif mengenai peran persepsi tentang lingkungan kerja psikososialterhadap komitmen organisasional.

\section{Bibliografi}

Allen, J.P., \& Meyer, J.A. (1997).Commitment in the Workplace: Theory, Research, and Application. California: SAGE Publications, Inc.

Ash-shafti, A.M.K. 2003. Iltizam - Membangun Komitmen Seorang Muslim. (Terjemahan: Abdul Hayi dan Sabarudin). Jakarta: Gema Insani

Handoko, H. (2011).Manajemen Personalia dan Sumber Daya Manusia. Yogyakarta: BPFE UGM.

Jewell, P.\& Siegell, R. (1998).Psikologi Industri/Organisasi Modern. (Terjemahan: A, Hadyana Pudjaatmaka dan Meitasari). Jakarta: Penerbit Arcan

Oktorita, Yenny., Rosyid, Haryanto, F., \& Lestari, Anita. (2001). Hubungan antara Sikap terhadap Penerapan Program K3 dengan Komitmen Karyawan pada Perusahaan. Jurnal Psikologi. Fakultas Psikologi UGM. Tahun XXVII, No. 2, Desember 2001, 116-132

Robbins S.P., \& Judge. (2007).Perilaku Organisasi (Terjemahan: Hadyana Pujaatmaka). Jakarta: Salemba Empat

Rahman, N.M., Muhammad, N., Othman, A.S. (2006). The Relation between Islamic Work Ethics and Organizational Commitment: a Case Analysis. Manalysian Manusiament Review, 41 (1): 79-89

Sopiah (2008).Perilaku Organisasi. Yogyakarta: Penerbit Andi 